\title{
Effect of magnesium sulphate and L-tryptophan and genotype on the feed intake, behaviour and meat quality of pigs
}

\author{
Panella-Riera, N., Velarde, A., Dalmau, A., Fàbrega, E., Font i Furnols, M., Gispert, M., Soler, \\ J., Tibau, J., Oliver, M.A. \& Gil, M.
}

Livestock Science, 2009, 124:277-287.

\begin{abstract}
Sixty-nine entire male pigs with different halothane genotype (homozygous halothane positive $-\mathrm{nn}-, \mathrm{n}=36$; and homozygous halothane negative $-\mathrm{NN}-, \mathrm{n}=33$ ) were fed with a supplementation of magnesium sulphate $(\mathrm{Mg})$ and/or ${ }_{\mathrm{L}}$-tryptophan $(\mathrm{Trp})$ in the diet for 5 days before slaughter. Animals were housed individually and were submitted to stressful ante mortem conditions (mixed in the lorry according to treatments and transported $1 \mathrm{~h}$ on rough roads). Individual feed intake was recorded during the 5-day treatment. At the abattoir, pig behaviour was assessed in the raceway to the stunning system and during the stunning period by exposure to $\mathrm{CO}_{2}$. Muscle $\mathrm{pH}$, colour, water holding capacity, texture and cathepsin activities were determined to assess meat quality. The number of pigs with an individual feed intake lower than $2 \mathrm{~kg} /$ day was significantly different among diets $(\mathrm{P}<0.05$; Control: 8.7\%; Mg\&Trp: 43.5\%; Trp: $17.4 \%$ ) and they were considered to have inadequate supplement intake. During the ante mortem period, $15.2 \%$ of pigs included in the experiment died, and this percentage decreased to $8.7 \%$ in those pigs with a feed intake $>2 \mathrm{~kg} / \mathrm{day}$, all of them from the stress-sensitive pigs (nn). In general, no differences were observed in the behaviour of pigs along the corridor leading to the stunning system and inside the $\mathrm{CO}_{2}$ stunning system. During the stunning procedure, Trp diet showed shorter periods of muscular excitation than control and Mg\&Trp diets. The combination of a stressful ante mortem treatment and Mg\&Trp supplementation led to carcasses with high incidence of severe skin lesions. Different meat quality results were found when considering all pigs or considering only those with adequate supplement intake. In this later case, Trp increased pH45 (6.15) vs Control diet (5.96) in the Longissimus thoracis (LT) muscle $(\mathrm{P}<0.05)$ and $\mathrm{pH}$ at $24 \mathrm{~h}$ (Trp: 5.59 vs C: 5.47) led to a higher incidence of dark, firm and dry (DFD) traits in $\mathrm{SM}$ muscle $(\mathrm{P}<0.05)$. Genotype affected negatively all the meat quality
\end{abstract}


traits. Seventy-five percent of LT and $60.0 \%$ of the SM muscles from nn pigs were classified as pale, soft and exudative (PSE), while none of the NN pigs showed these traits $(\mathrm{P}<0.0001)$. No significant differences were found between genotypes on the incidence of DFD meat.

Due to the negative effects observed in the Mg\&Trp group in feed intake and carcass quality, the utilization of a mixture of magnesium sulphate and tryptophan is not recommended.

\subsection{Introduction}

Carcass and meat quality of finishing pigs can be affected by genetics as well as by the pre-slaughter handling. During this period, pigs experience some of the most stressful situations in their life (Gispert et al., 1996; Guàrdia et al., 2004). The effect of the stress on the muscle metabolism is especially dramatic on the pigs carrying the halothane gene, $n$ : nn pigs have a mutation in the RYR1 gene which codifies one of the calcium release channels of sarcoplasmic reticulum: the ryanodine receptor (Fujii et al., 1991). This mutation makes pigs particularly sensitive to acute stress, which is the main cause of death before slaughter (Barton-Gade et al., 1998) and of the development of pale, soft and exudative meat (PSE; Jensen \& Barton-Gade, 1985; Oliver et al., 1993). Despite these negative effects, the halothane gene is still used in Spanish commercial herds (Oliver et al., 1993) because it enables producers to target carcass specifications of high value according to the price payment grids based on carcass weight and lean content (Gispert \& Font i Furnols, 2007). Nevertheless, meat from halothane-free pigs (NN) submitted to pre-slaughter stressful stimuli can also become PSE (Honkavaara, 1988).

The stunning procedure may also modify the final carcass and pork quality (Channon et $a l .$, 2000; EFSA, 2004). The $\mathrm{CO}_{2}$ stunning system is one of the approved methods of stunning pigs in Europe (EC, 1993). Despite its positive effects on meat quality in comparison to the electrical stunning (Velarde et al., 2001), it has been questioned on welfare grounds as $\mathrm{CO}_{2}$ itself has been described as an aversive gas (Raj \& Gregory, 1995).

Therefore, an adequate strategy is needed to avoid the negative effect of the ante mortem handling of pigs, especially those with the halothane gene. Some studies suggest that magnesium $(\mathrm{Mg})$ or $_{\mathrm{L}}$-tryptophan $(\mathrm{Trp})$ supplementation of the diet of pigs 
can help to alleviate it and improve meat quality (D'Souza, et al., 1998; Kietzmann \& Jablosnki, 1985; Peeters et al., 2005). $\mathrm{Mg}$ is a cofactor essential in many metabolic pathways (Stryer, 1988), it depresses the muscular activity due to its antagonism towards calcium and counteracts catecholamine effects in stressful situations by reducing levels of catecholamine in plasma (D'Souza, et al., 1998; Kietzmann \& Jablosnki, 1985). Some authors reported a positive effect of $\mathrm{Mg}$ supplementation on pig behaviour (Peeters et al., 2005), water holding capacity of meat (WHC), pork colour and pork texture (D'Souza et al., 1998; Caine et al., 2000; Frederick et al., 2006). Nevertheless, non conclusive results have been obtained when comparing the effect of $\mathrm{Mg}$ supplementation within carriers (Nn) and non-carriers (NN) of the Halothane gene (Apple et al., 2000; Caine et al., 2000; Panella-Riera et al. 2008).

Trp, as a precursor of serotonin (Fernstrom \& Wurtman, 1971), has a potential sedative effect by promoting its synthesis in the brain (Leathwood, 1987). Contradictory results have been found with Trp supplementation with respect to meat quality: some authors claimed an increase of post-mortem muscle $\mathrm{pH}$ (Henry et al., 1996) or a reduction of incidence of PSE meat (Adeola \& Ball, 1992 and Henry et al., 1996), while others reported no significant effect or even poorer meat quality (Guzik et al., 2006; Li et al., 2006).

A previous study reported the effect of magnesium carbonate $\left(\mathrm{MgCO}_{3}\right)$ and $\operatorname{Trp}$ on the welfare and on the carcass and meat quality of two halothane pig genotypes (NN and nn) under non-stressful conditions (Panella-Riera et al., 2008). The aim of the present work was to evaluate the effect of dietary supplementation with magnesium and Trp on feed intake, mortality, animal behaviour and carcass and meat quality characteristics of $\mathrm{NN}$ and nn pigs under stressful ante mortem conditions.

\subsection{Materials and methods}

\subsubsection{Animals and diets}

Sixty-nine pure-breed entire male pigs were used in this study: $36 \mathrm{NN}$ (24 Landrace and 12 Large White) and $33 \mathrm{nn}$ (Pietrain), with an average live weight at slaughter of 108.5 $\pm 8.3 \mathrm{~kg}$. They were housed individually from the age of 90 to 150 days in pens with a

space allowance of $4 \mathrm{~m}^{2}$, with visual and olfactory contact between each other. All were fed the same commercial diet $(30.0 \%$ barley, $25.0 \%$ soy, $15.0 \%$ maize, $11.9 \%$ wheat 
and a vitamin/mineral source) until 5 days before slaughter. The diet contained $87.9 \%$ of dry matter and $14.1 \mathrm{MJ} / \mathrm{kg}$ of digestible energy on fresh matter.

Five days before slaughter three diet groups were established for each genotype: Control group, with no supplement; Mg\&Trp group, control diet supplemented with $1.2 \mathrm{~g}$ elemental $\mathrm{Mg}$ and $8 \mathrm{~g}$ L-tryptophan per $\mathrm{kg}$; and Trp group, control diet supplemented with $8 \mathrm{~g}$ L-tryptophan per $\mathrm{kg}$ (Table IV.3-1). Diets were designed considering a minimum of feed intake of $2 \mathrm{~kg}$ /day during the monitoring period (initial pig weight: $105.6 \pm 7.0 \mathrm{~kg}$ ). Individual feed intake was monitored for each pig during the 5 days prior to slaughter.

\subsubsection{Ante mortem treatment and slaughter procedure}

Two batches of 36 and 33 animals were slaughtered on two different days. The animals from each treatment were mixed in 6 different groups according to diet and genotype. The day before slaughter, pigs were fasted on-farm during $9 \mathrm{~h}$ and then transported from the IRTA pig experimental station to the IRTA experimental abattoir for $1 \mathrm{~h}$ on rough secondary roads. Lairage time for the first pig slaughtered was about $30 \mathrm{~min}$ and for the last one was $7 \mathrm{~h}$ as they were slaughtered individually by exsanguination, after stunning with $90 \% \mathrm{CO}_{2}$. In each batch, the animals from the 6 groups were slaughtered alternatively (3 diets x 2 genotypes).

\subsubsection{Animal behaviour measurements}

Behaviour measurements were recorded along the corridor leading to the stunning system and in the $\mathrm{CO}_{2}$ stunning unit following the procedure described by Panella-Riera et al. (2008). The raceway was $412 \mathrm{~cm}$ long and $60 \mathrm{~cm}$ wide, and it was lined with steel panels of $90 \mathrm{~cm}$ height to prevent the pig from seeing out of the raceway. It was divided into three different sections: raceway, ramp and entrance. Pigs were separated from the group, placed individually at the starting point of the raceway and allowed to cross the raceway to enter the $\mathrm{CO}_{2}$ stunning crate. If after 1 min. the animal was reluctant to move, it was gently pushed into the next section. The following behavioural variables were scored in each section: presence of retreat attempts (when the pig backed away; Dodman, 1977), time to perform the first retreat attempt and time to cross each section (the time taken to cross the raceway, the entrance and the ramp).

The $\mathrm{CO}_{2}$ stunning unit was a dip-lift system (Butina Aps, Copenhagen) that contained a crate $(195 \times 90 \times 61 \mathrm{~cm})$ with perforated floor to facilitate the distribution of the gas 
inside. The $\mathrm{CO}_{2}$ concentration at the bottom of the crate was $90 \%$ by volume in atmospheric air. The stunning procedure lasted 132s (23s descending, 23s ascending and $86 \mathrm{~s}$ at the bottom of the crate). Behavioural variables were monitored during the exposure to the $\mathrm{CO}_{2}$ to determine the aversion to the gas: presence of retreat attempts, first retreat attempt (time to perform the first retreat attempt in the $\mathrm{CO}_{2}$ unit), presence of gasp (number of very deep breath through a wide open mouth, which may involve stretching of the neck and which was considered to be an indicator of the onset of breathlessness; Velarde et al., 2007), first gasp (time to perform the first gasp), presence of muscular excitation (number of fast running movements across the stunning box and sometimes raising their forelegs on the side of the wall of the crate either prior to, or at the time it was losing its posture; Raj \& Gregory, 1996), first and last muscular excitation (time to perform the first and last muscular excitation) and time of loss of posture (it was considered when the animal fell in the crate and was recorded as the first indicator of onset of unconsciousness; Raj \& Gregory, 1996). The presence of gagging, as low frequency inhalations with its neck towards its front legs and, sometimes, emitting sounds similar to snore (Gregory et al., 1987), was also recorded. All recording times were synchronised with the time the pigs started to descend into the well.

\subsubsection{Chemical analysis of feed}

The feed was analysed for crude protein, crude fibre, ether extract, humidity and ash according to the Association of Official Analytical Chemists (AOAC, 1990). Magnesium and Trp content were also determined (AOAC, 1990; Table 1).

\subsubsection{Measurements of carcass and meat quality}

After sticking, and when carcasses were hoisted on the bleeding rail, fresh scratches on the skin were inspected and subjectively scored according to their severity (BartonGade et al. 1996).

\section{Carcass measurements.}

The carcass weight $(\mathrm{kg})$ without flare fat, kidneys and diaphragm was determined individually. Carcass grading was carried out using the Fat-o-Meat'er grading probe (FOM) in the left side of the carcass and carcass lean percentage was estimated using the Spanish official equation (Gispert \& Diestre, 1994). Visual conformation was determined following the photographic model for EC Pig Grading Grid (1= very good conformation to $4=$ very poor conformation). 
Meat quality measurements.

The left side of the carcass was used to perform meat quality measurements on the Longissimus thoracis (LT, at last rib level) and Semimembranosus (SM) muscles. Muscle $\mathrm{pH}$ at $45 \mathrm{~min}(\mathrm{pH} 45)$ and $\mathrm{pH}$ at $24 \mathrm{~h}(\mathrm{pHu})$ post-mortem $(\mathrm{pm})$ were measured using a portable $\mathrm{pH}$-meter KNICK equipped with a Xerolyt electrode. Electrical conductivity at $24 \mathrm{~h}$ pm (ECu) was measured using a Pork Quality Meater (PQM-I, INTEK Aichach, Germany). Muscles (LT and SM) showing pH45 $\leq 5.8$ were classified as PSE meat (Honkavaara, 1988), whereas those presenting $\mathrm{pHu}$ values $\geq 6.00$ were classified as DFD (Oliver et al., 2001).

Sampling.

Samples from the LT muscle were collected at $24 \mathrm{~h} \mathrm{pm}$, at the $3 / 4$ last rib level, to determine drip losses, following the reference method supported by OECD (Honikel, 1996).

Colour measurements were carried out at the last rib level with a Spectrophotometer Minolta 2002 on the CIELab space (CIE, 1976) using D65 illuminant and $10^{\circ}$ standard observer. Before the measurement, a slice of $0,2 \mathrm{~mm}$ was removed, and the colour was measured after 5 min blooming.

After chilling, at $24 \mathrm{~h} \mathrm{pm}$ the LT muscle was removed from the left side of each carcass to take the samples for posterior analysis of intramuscular fat, cathepsin activities and texture. Samples of SM muscle were also taken. They were vacuum-packed in aluminium bags and frozen at $-20^{\circ} \mathrm{C}$ until analysis.

Intramuscular fat was analysed by Near Infrared Transmittance spectroscopy (NIT, Infrared, 1265, Tecator; Gispert et al., 1997) in the LT muscle at the last rib level.

Cathepsin activity measurements were performed in the LT and SM muscles at $24 \mathrm{~h} \mathrm{pm}$. After removing the subcutaneous fat and connective tissue, muscles were ground and kept at $-20^{\circ} \mathrm{C}$ until further analysis. Cathepsins were extracted according to the method of Etherington et al. (1990). Cystein proteinases B and L were assayed fluorimetrically using the method of Etherington and Wardale (1982). One unit activity was defined as the amount of enzyme hydrolysing $1 \mathrm{nmol}$ of substrate $\min ^{-1}$ at $37{ }^{\circ} \mathrm{C}$. Protein concentration of the enzymatic extracts was determined by the method of Lowry et al. (1951) using bovine serum albumin as standard. Results are given in nIU (nmol. $\mathrm{min}^{-1} \cdot \mathrm{g}$ $\operatorname{protein}^{-1}$ ). 
Instrumental tenderness was determined on boneless LT muscle. Samples were thawed for $24 \mathrm{~h}$ at $4{ }^{\circ} \mathrm{C}$ in their vacuum-packed aluminium bag and then cooked in a convection oven pre-heated to $110{ }^{\circ} \mathrm{C}$ to an internal temperature of $75^{\circ} \mathrm{C}$. Afterwards, they were allowed to come to room temperature before a minimum of six pieces $3.0 \times 1.5 \times 1.5 \mathrm{~cm}$ was removed per chop. All pieces were sheared using a MTS Aliance RT/5 texture analyzer (MTS System Corp., Eden Praine, MN, USA) equipped with a Warner Bratzler blade with crosshead speed set at $2 \mathrm{~mm} / \mathrm{s}$, and peak load $(\mathrm{kg})$, modulus $\left(\mathrm{kg} \cdot \mathrm{mm}^{-1}\right)$ and peak energy (kg.mm) were recorded (Møller, 1980).

\subsubsection{Statistical analyses}

Statistical analysis was performed using the software Statistical Analysis System (SAS, 2001).

\section{Behavioural data.}

Behavioural observations were count data, time intervals and binary data. As data were not normally distributed, the statistical analysis was performed using Proc GENMOD of SAS with binomial, multinomial, Poisson or negative binomial distributions (Cameron and Trivedi, 1998). A binomial distribution with logit model as link function was used to analyse the incidence of pigs showing voluntary movement, presence of retreat attempts and presence of muscular excitation. A multinomial distribution with cumlogit model as link function was used in retreat attempts in the raceway, ramp entrance and the whole way and the time to perform the first retreat attempt in the stunning system. A Poisson distribution with log model as a link function was used with the time to perform the $1^{\text {st }}$ sniffing, time to start the $1^{\text {st }}$ and the last muscular excitation, time to loss of posture and the time to the first gasp. Negative binomial distribution with a log model as a link function was used for the time to cross the raceway, time to perform the $1^{\text {st }}$ retreat attempt in the raceway, and time to perform the $1^{\text {st }}$ gagging in the stunning unit. The effects studied were diets (Control, Mg\&Trp, Trp) and genotype (NN, nn) and the interaction between them. Significance was fixed at $\mathrm{P}<0.05$ in all cases. The residual maximum likelihood was used as a method of estimation. In the case of Poisson and negative binomial distributions, the least square means of fixed effects (LSMEANS) were used when analysis of variance indicated differences. In the case of multinomial distribution, the estimate statements were used.

Carcass and meat quality data. 
Feed intake, carcass parameters and meat quality parameters were analysed using the GLM procedure. Genotype and diet were considered as fixed effects (the interaction was not significant in any of the carcass and meat quality variables studied). The day effect was included in the model as a blocking effect and carcass weight was included as a covariate when it was significant. Differences among diets or genotypes were adjusted with Tukey's honestly significant difference (HSD). Significance level was fixed at $\mathrm{P}<0.05$, although significances at $\mathrm{P}<0.1$ were taken into account as a tendency in some cases. The least square means of fixed effects (LSMEANS) were used when analysis of variance indicated differences.

Two types of statistical analysis were used, the first one included all pigs in the model and the second one included only pigs with feed intake $>2 \mathrm{~kg} / \mathrm{day}$.

\subsection{Results}

\subsubsection{Feed intake}

Table IV.3-2 shows the feed intake according to diets and genotypes. No differences among diets $(\mathrm{P}>0.05)$ were found during the 5-day treatment on the daily feed intake, whereas NN pigs showed higher feed intake $(\mathrm{P}<0.001)$ than nn $(3.26 \mathrm{vs} 2.13 \mathrm{~kg} / \mathrm{day})$.

As stated above, diet supplements were included in the feed considering a minimum feed intake of $2 \mathrm{~kg} /$ day in order to meet the appropriate dose of $\mathrm{Mg}$ and/or Trp. Table IV.3-2 also shows the number of pigs with feed intake higher and lower than $2 \mathrm{~kg} /$ day (adequate and inadequate supplement intake, respectively). Diet supplements had a significant effect $(\mathrm{P}<0.05)$ in both cases in the number of pigs showing adequate and inadequate supplement intake. When considering pigs with adequate feed intake $(>2$ $\mathrm{kd} /$ day), no differences in the daily feed intake were observed. However, there were significantly more pigs from the Mg\&Trp group with feed intake lower than $2 \mathrm{~kg} / \mathrm{day}$ (Mg\&Trp: 10 pigs vs C: 2 and Trp:4 pigs). Regarding genotypes, NN had higher feed intake than nn ones, and these differences were also observed when pigs with adequate supplement intake were considered (feed intake $>2 \mathrm{~kg} /$ day).

Sixteen pigs showed feed intake lower than $2 \mathrm{~kg} / \mathrm{d}, 5$ of them with extremely low values $(<0.5 \mathrm{~kg} / \mathrm{d})$. Nine of the 16 pigs with feed intake $<2 \mathrm{~kg} /$ day had also a negative growth rate, 4 from the Trp group and 10 from the Mg\&Trp group (Figure IV.3-1) . 


\subsubsection{Mortality}

The mortality rate during the ante mortem treatment is shown in Table IV.3-3. When considering all the animals, 5 pigs died, all from the stress-sensitive genotype (nn). Regarding diets, none of the dead pigs belonged to the Trp group, 2 pigs were from the Mg\&Trp group (8.7\%) and 3 from the control one (13.0\%). Among pigs with an adequate supplement intake ( $>2 \mathrm{~kg} /$ day), $4.8 \%$ of Control and $7.7 \%$ of the Mg\&Trp pigs died.

\subsubsection{Animal behaviour in the experimental abattoir}

Table IV.3-4 shows the behaviour of pigs in the corridor that led to the $\mathrm{CO}_{2}$ stunning system, considering those pigs with a feed intake $>2 \mathrm{~kg} /$ day. There were no differences in the proportion of pigs showing retreat attempts among diets $(\mathrm{P}>0.05)$ in the three sections of the raceway, and no differences were found when the whole way was considered. Genotype had a significant effect $(\mathrm{P}<0.05)$ on the proportion of pigs showing retreat attempts at the entrance of the $\mathrm{CO}_{2}$ stunning system, as all the pigs that showed retreat attempts were NN pigs (NN: $20.6 \%$; nn: 0\%).

The behaviour of the pigs was assessed in the $\mathrm{CO}_{2}$ stunning unit during the descent into the pit. No differences were found between genotypes and among diets. The first behaviour exhibited was the time to perform the first retreat attempt $(4.4 \pm 0.3 \mathrm{~s})$, followed by the sniffing $(9.0 \pm 0.4 \mathrm{~s})$, and the gasping $(22.1 \pm 0.5 \mathrm{~s})$. The loss of posture took place after $27.8 \pm 0.8 \mathrm{~s}$, and gagging took place at $47.8 \pm 1.2 \mathrm{~s}$. Muscular excitation began at $21.6 \pm 0.4 \mathrm{~s}$, finished at $35.5 \pm 0.8 \mathrm{~s}$ and lasted $13.5 \pm 0.8 \mathrm{~s}$. No differences in the time to begin muscular excitation among diets were observed, but a significant effect was found in the duration $(\mathrm{P}<0.001)$ : Trp pigs showed shorter muscular excitation than other diet groups (Trp: 9.9s vs C: 16.6 and Mg\&Trp: 14.0s).

\subsubsection{Carcass and meat quality}

Diet supplements did not have any effect $(\mathrm{P}>0.05)$ on the carcass quality variables considering those pigs with feed intake $>2 \mathrm{~kg}$ /day (Table IV.3-5). No differences among diets were found in any of them. Besides, genotype had a significant effect $(\mathrm{p}<0.001)$ on almost of the carcass variables (body weight, lean content, carcass length, fat depth at 
last rib level and conformation,). Carcasses from nn pigs were shorter, leaner, showed higher conformation and had less fat depth at last rib level than NN ones.

Carcass skin lesions were scored according to the procedure described by Barton-Gade et al. (1996). In general, no differences were found in the number of pigs showing skin lesions (Table 6). More than $85 \%$ of pigs had skin lesions, with no significant differences among diets and between genotypes. Regarding the severity of skin lesions, significant differences were observed among diets. Mg\&Trp pigs were more likely to show more intense skin lesions than $\mathrm{C}$ pigs.

Two different data sets depending on the feed intake were studied to analyse meat quality traits. The first one considered all pigs and the second one considered only pigs with feed intake higher than $2 \mathrm{~kg}$ /day. Table IV.3-7 shows significance levels of meat quality traits considering both statistical analyses, according to diet or halothane gene effect. When considering all the pigs the diet tended to affect $\mathrm{pH}$ values at $24 \mathrm{~h}$ in $\mathrm{SM}$ muscle $(\mathrm{P}=0.010 ; \mathrm{C}: 5.59, \mathrm{Mg} \&$ Trp: 5.79, Trp: 5.67), electrical conductivity in LT muscle $(\mathrm{P}=0.09$; $\mathrm{C}: 6.8, \mathrm{Mg} \& \operatorname{Trp}: 7.0$, Trp: $5.9 \mathrm{mS})$, drip loss in LT muscle $(\mathrm{P}=0.08$; C: 8.7 , Mg\&Trp: 7.6, Trp: 7.5\%), and the $\mathrm{L}^{*}$ value in LT muscle (P=0.05; C: 54.08, Mg\&Trp: 50.92, Trp: 51.22). However, when considering pigs with feed intake higher than $2 \mathrm{~kg} / \mathrm{d}$, diet had only a significant effect on $\mathrm{pH}$ at $45 \mathrm{~min}$ in the LT muscle (C: 5.96 , Mg\&Trp: 5.96, Trp: 6.15; Table IV.3-6).

The same statistical analyses were performed on the incidence of PSE and DFD meat. Overall, in the LT muscle $34.9 \%$ of the carcasses showed PSE and 4.8\% DFD traits. In the SM muscle, $28.6 \%$ of carcasses showed PSE and $11.1 \%$ showed DFD condition. Table 5 shows the percentage of pigs with feed intake $>2 \mathrm{~kg} /$ day that showed PSE and DFD traits according to diets and genotypes. Diets did not affect the percentage of pigs with PSE traits in LT or SM muscles but affected the number of carcasses showing DFD traits in the SM muscle, with a higher percentage in the Trp group.

Genotype affected significantly most of the meat quality variables (Table IV.3-5 and Table IV.3-7). Similar significance levels were found either analysing data considering all pigs and considering only those with feed intake higher than $2 \mathrm{~kg} / \mathrm{day}$, with the exception of the $\mathrm{pH} 24 \mathrm{~h}$ in the SM muscle: considering all pigs, no differences were found $(\mathrm{P}=0.20)$ whereas a significant effect was observed with pigs eating more than $2 \mathrm{~kg}$ feed/day, $\mathrm{NN}$ pigs showing higher $\mathrm{pH} 24(\mathrm{P}=0.02)$. 
In comparison to $\mathrm{NN}$ pigs, $\mathrm{nn}$ ones showed lower $\mathrm{pH}$ at $45 \mathrm{~min}$, lower $\mathrm{pH}$ at $24 \mathrm{~h}$, higher electrical conductivity and loin drip loss and higher value of $\mathrm{L}^{*}, \mathrm{a}^{*}$ and $\mathrm{b}^{*}$ variables than NN pigs (Table IV.3-5). A significant genotype effect was found in the percentage of pigs showing PSE traits $(\mathrm{P}<0.0001), 75.0 \%$ of LT and $60.0 \%$ of the SM muscles from nn pigs were PSE, while none of the NN pigs showed PSE traits (Table IV.3-5).

The activity of cathepsin B in LT muscle tended to be lower in the Mg\&Trp and Trp groups than in the $\mathrm{C}$ group ( $\mathrm{P}=0.07$; Table IV.3-8). No significant effect was observed among diets in the activity of cathepsin B+L enzymes. Genotype affected cathepsin $\mathrm{B}+\mathrm{L}$ activity in $\mathrm{LT}$ and $\mathrm{SM}$ muscles $(\mathrm{P}<0.05)$ : $\mathrm{nn}$ pigs showed higher enzymatic activity than NN pigs; but no effect was found in cathepsin B enzymatic activity (Table IV.3-8). Texture measurements were performed on non-aged meat (frozen at $24 \mathrm{~h} \mathrm{pm}$ ). The values of shear force (Warner-Bratzler test) neither depended on the diet supplements nor on the pig genotype $(\mathrm{P}>0.1)$.

\subsection{Discussion}

\subsubsection{Feed intake and mortality}

The transport between the farm and the experimental abattoir was performed under stressful conditions. As a result 5 pigs died, all of them being halothane positive (nn). Mortality during transportation to slaughter plant reflects the high levels of stress suffered by the pigs during the journey. A genetic susceptibility, as well as some inadequate procedures when loading pigs may add sufficient stress to poor transport conditions to result in deaths (Warris, 1998) and, as stated by Gispert et al. (1996), high mortality rates may lead to important economic losses. Our results are consistent with the fact that the halothane gene is related to a high sensitivity to stress (Fàbrega et al., 2002) and that if nn pigs are submitted to minimal stressful conditions, losses before slaughter can be avoided (Panella-Riera et al., 2008). In accordance with these results, Geers et al. (1994) and Pérez et al. (2002) also found a greater effect of the handling and transport before slaughter on nn pigs than on $\mathrm{NN}$ pigs.

In studies assessing the effect of a diet supplement, it is very important to consider the individual feed intake especially when the supplement is provided through the feed. In the present study, the feed intake was measured individually during the 5-day treatment. 
Supplemented feeds were designed considering a minimum feed intake of $2 \mathrm{~kg} / \mathrm{day}$ for pigs with a life weight of $105.7 \pm 7.0 \mathrm{~kg}$ (Fàbrega et al., 2003). Therefore, pigs with feed intake lower than $2 \mathrm{~kg}$ /day did not ingest enough supplements, $\mathrm{Mg}$ and/or Trp. When considering pigs with the desired supplement intake, only 2 died, one from the control group and the other one from the Mg\&Trp group. Further research should be carried out to ascertain whether there is any relationship between the mortality of pigs and the Trp supplementation as it has been suggested that the sedative effect of this amino acid could counteract the negative effect of a stressful pre-slaughter treatment (Kietzmann \& Jablonski, 1985).

One of the hypotheses of the present study was that after removing pigs with inadequate supplement intake, diet effect on pigs' behaviour and meat quality may vary. Therefore, data were analysed firstly, considering all pigs, and secondly including only pigs with an adequate supplement intake (> $2 \mathrm{~kg} / \mathrm{day})$.

No differences among diets were found in the average feed intake, probably due to the wide variability in feed intake within treatments. However, differences were observed in the number of pigs with feed intake lower than $2 \mathrm{~kg} / \mathrm{day}$. In the Mg\&Trp group there were significantly more pigs with inadequate supplement intake than in Control group. All the pigs that lost weight during the treatment had a feed intake lower than $2 \mathrm{~kg} / \mathrm{d}$. Among them, two different groups can be distinguished. The first one that lost between 0.4 and $0.6 \mathrm{~kg} /$ day had a feed intake lower than $0.5 \mathrm{~kg}$ during the treatment, indicating that they scarcely ate (Figure IV.3-1). All these pigs belonged to the supplemented diets (Mg\&Trp and Trp groups) so it could be suggested that, apart from the effect of changing the diet, pigs did not like the new feed. The second group, all from the Mg\&Trp group, includes pigs with feed intake from 1 to $2 \mathrm{~kg} / \mathrm{day}$ that lost weight anyway. This may be due to the potential laxative/purgative effect associated with magnesium sulphate (Frederick et al., 2004; O’Quinn et al., 2000), as diarrhoea was observed in Mg\&Trp pens. D’Souza et al. (1999) suggested that although aspartate, chloride and sulphate salts of $\mathrm{Mg}$ were equally effective in reducing the incidence of PSE pork, $\mathrm{MgSO}_{4}$ could be the best choice because magnesium aspartate was an expensive source of $\mathrm{Mg}$ and the chloride salt had chemical properties that make its inclusion in the feed difficult. Hamilton et al. (2002) also concluded that $\mathrm{MgSO}_{4}$ produced the greatest improvement in meat quality traits; more than proteinate and proprionate sources. However, none of these studies reported a potential laxative effect 
of the $\mathrm{MgSO}_{4}$ affecting muscle glycogen stores and therefore the post-mortem energy metabolism.

To our knowledge, few studies have reported the effect of 5-day $\mathrm{Mg}$ and/or $\operatorname{Trp}$ supplementation on feed intake and none of them found any effect of the inclusion of supplements of Mg or Trp in the diet (Caine et al., 2000; Peeters et al., 2005). However, most of them reported an effect of $\mathrm{Mg}$ supplements on meat colour (Caine et al., 2000; D'Souza et al., 1998; Hamilton et al., 2002) and water holding capacity (D’Souza et al., 1998, 1999; Hamilton et al., 2002; Schaefer et al., 1993).

When Frederick et al. (2004) studied the effect of Mg supplementation through drinking water, no differences in feed intake and water disappearance were found among different $\mathrm{Mg}$ concentrations.

On the other hand, the relationship between Trp consumption and the feed intake was extensively discussed by Le Floc'h \& Sève (2007). While Trp deficiency was related to a reduction of appetite and feed intake for finishing pigs (Henry et al., 1992), an excess of $4 \%$ of Trp in the diet was also reported to decrease the feed intake in finishing pigs (Chung et al., 1991).

\subsubsection{Animal behaviour in the experimental abattoir. Aversion to the exposure to the $\mathrm{CO}_{2}$}

The first behaviour that pigs exhibited in the cage when they were exposed to the gas was retreat attempts, followed by sniffs and gasp indicating the onset of breathlessness according to Raj (1999) and Gregory et al. (1987). Almost simultaneously, pigs showed muscular excitation from $21.6 \pm 0.4$ to $35.3 \pm 0.8$ s lasting an average time of $13.5 \pm$ 0.8s. Similar results were found by Rodriguez et al. (2008), who found muscular excitation appeared between 19 and 39s.

Our results indicated that genotype tended to have an effect on the duration of muscular excitation, lasting $14.6 \pm 1.14 \mathrm{~s}$ for the nn pigs and $12.8 \pm 1.00$ s for the NN ones. Diet had a significant effect, as the muscular excitation period in Trp-group was shorter than in $\mathrm{C}$ and $\mathrm{Mg} \& \mathrm{Trp}$ ones. In contrast to these results, no differences between genotypes (NN vs $\mathrm{nn}$ ) and among supplemented-diets (Control, Mg, Trp) were found in the previous experiment carried out under conditions of minimal stress during transport (Panella-Riera et al., 2008). 
Rodriguez et al. (2008) suggest that the onset of muscular excitation is likely to occur when pigs are still conscious. On the other hand, the loss of posture during the exposure to gas has been considered by some authors to be the first behavioural indicator of the onset of unconsciousness (Raj \& Gregory, 1996). In the present study, pigs lost their posture at $27.8 \pm 0.8 \mathrm{~s}$ after the beginning of the stunning procedure, taking place during the presence of muscular excitation. In fact, for $13.2 \%$ of animals the muscular excitation appeared earlier than the loss of posture, for 5.7\% appeared at the same time, and for $81.1 \%$ the loss of posture took place before the appearance of muscular excitation. So it is not clear if these muscular excitations are escape attempts, as described by Raj \& Gregory (1996) or involuntary convulsions, as described by Forslid (1987).

In general, no differences were found among diets and between genotypes on animal behaviour. However, in agreement with Raj (2004) and Velarde et al., (2007), our results indicated that the induction of unconsciousness with carbon dioxide, by using a dip-lift system, could be distressing to animals and thus compromise the welfare of pigs. Therefore, the meat industry should be encouraged to consider potential alternatives (Raj, 2004; Velarde et al., 2007). The role of Trp in the muscular excitation of animals inside the system needs further investigation.

\subsubsection{Carcass and meat quality}

Carcass quality was positively affected by halothane genotype, with the nn pigs having leaner carcasses and higher conformation (lower score) than the NN ones. These are considered relevant traits for ham production in Spain and for that reason halothane genotype is still desired by many producers and the meat industry in Europe despite knowing the detrimental effects on pork quality. The negative effect of the halothane gene to meat quality traits has been extensively studied (e.g. Jensen \& Barton Gade, 1985; Channon et al., 2000; Gispert et al., 2000; Guàrdia et al., 2004). Accordingly, in the present study the nn pigs showed lower $\mathrm{pH}$ values and water holding capacity (higher drip loss and electrical conductivity) and paler meat ( $\mathrm{L}^{*}$ value) than the NN ones. Similar results were also obtained in the previous study under non-stressful ante mortem conditions (Panella-Riera et al., 2008).

Supplementation with $\mathrm{Mg}$ and/or Trp had no effect $(\mathrm{P}>0.05)$ on midline back fat measurements, last rib fat depth and lean content (Table IV.3-5). These results are 
consistent with other studies that did not find any effect of $\mathrm{Mg}$ supplementation on fat and muscle measurements of pig carcasses after a 5-day treatment (Schaefer et al., 1993; D’Souza et al., 1998, 1999).

Carcass quality is also affected by the presence of skin lesions as this may determine the commercial application (Barton-Gade et al., 1996). In the present experiment, no differences were observed in the number of pigs showing skin lesions, as most of them had lesions on the skin. This may be explained by the fact that pigs tried to establish hierarchy at the lairage pens as until then they did not have the chance to do it. However, differences in the severity of these lesions were observed among diets. Mg\&Trp pigs were more likely to have more intense skin lesions than $\mathrm{C}$ ones. This may be related to the fact that these pigs may be hungry due to the laxative effect of magnesium sulphate. There is also some evidence that fasted pigs tend to fight more aggressively and for a longer time than fed pigs (Fernandez et al., 1995). According to Barton-Gade et al. (1996), a score of between 3 and 4 is unacceptable for most of the commercial applications, and even a score of 2 should be also considered unacceptable when carcasses are used for sensitive productions. In the case of Mg\&Trp diet, more than $83.3 \%$ of the carcasses showed a score higher than 3, and $100 \%$ of the carcasses had a score of $\geq 2$. Therefore, in the present experiment $83.3 \%$ of carcasses would be unacceptable for most commercial applications.

Meat quality traits were also studied. When taking into account all pigs, diet tended to affect $\mathrm{pH}$ at $24 \mathrm{~h}$ in SM muscle, electrical conductivity and drip loss in LT muscle and showed a statistically significant effect on colour (Table IV.3-7). As magnesium sulphate has been associated with a laxative effect, pigs may have had depleted muscle glycogen stores and, therefore it may produce meat with higher ultimate $\mathrm{pH}$, darker colour and higher water holding capacity (Lambooij, 2007). These differences were not found when the data were analysed with pigs with adequate supplement intake, as diets only had an effect on $\mathrm{pH}$ measured at $45 \mathrm{~min}$ at LT muscle.

As shown in Table IV.3-5, high incidence of pigs still showed PSE traits $\left(\mathrm{pH}_{45} \leq 5.8\right)$ after removing those with feed intake lower than $2 \mathrm{~kg} /$ day. A total of 16 pigs were removed from the statistical analysis for their inadequate supplement intake, most of them showing PSE traits ( 8 in the LT and 6 in the SM muscle), all of them nn pigs. These results confirm that the pre-slaughter treatment was indeed under stressful conditions, and also confirm the relationship between the halothane gene and the 
incidence of PSE meat. Besides, two pigs from the removed ones were classified as DFD $\left(\mathrm{pH}_{24 \mathrm{~h}} \geq 6.0\right)$ in the SM muscle which was the expected result as DFD meat occurs when the animals are fatigued and the glycogen energy store is exhausted at slaughter (Lambooij, 2007).

Despite the higher incidence of PSE, it is surprising the higher incidence of DFD meat among pigs with an adequate supplement intake. Pigs from the Trp group showed higher incidence of DFD in the SM muscle than C and Mg\&Trp, indicating that the supplementation of this amino acid could not completely avoid the depletion of the glycogen under a long stressful ante-mortem treatment, questioning the initial hypothesis. Further research is needed to ascertain whether the increase of the $\mathrm{pH}$ is due to the Trp supplement or the long stressful ante-mortem treatment. Henry et al. (1996) concluded that post-mortem muscle $\mathrm{pH}$ increased (both, $\mathrm{pH} 45$ and $\mathrm{pHu}$ ) in response to a long term Trp supplementation.

In agreement with the previous study (Panella-Riera et al., 2008), cathepsin activities were influenced by the genotype but not by the diet (Table 8): nn pigs showed higher activity than NN ones. Genetic type is known to affect cathepsin activity (Hernández et al., 2004; Plastow et al., 2005).

No differences were found between the two genotypes with instrumental measurements (Shear force test). However the panel test carried out within the same experiment found that the meat from nn pigs was harder than NN ones (Panella et al., 2005). Controversial results have been published. De Smet et al.,(1996) did not find any differences with instrumental measurements between genotypes. However, Moelich et al. (2003) and Murray et al. (1989) reported higher shear force values in meat from nn pigs than in meat from $\mathrm{NN}$ pigs.

\subsection{Conclusions and implications}

When studying the use of diet supplements, the individual measurement of feed intake should be a requirement as it allows the detection of pigs with inadequate supplement intake, even when the average feed intake is the expected value.

Potential side effects of the diet supplements should be taken into account as they may lead to misleading conclusions. The inclusion of a mixture of magnesium sulphate and tryptophan in the diet did not show any advantage due to the laxative effect of 
magnesium sulphate, showing lower feed intake. The Mg\&Trp group showed higher probability of having severe skin lesions in comparison to Control and Trp groups. From the results of this study the utilization of a mixture of magnesium sulphate and tryptophan is not recommended.

Trp reduced the duration of muscular excitation when animals were stunned with high concentrations of $\mathrm{CO}_{2}$, and pigs showed the same probability as control pigs of having severe skin lesions. An increase of $\mathrm{pH}$ at $45 \mathrm{~min} \mathrm{pm}$ in the LT muscle and the percentage of pigs showing DFD traits in the SM muscle were observed. Further research is needed to ascertain whether Trp can prevent the mortality related to high levels of stress during the pre-slaughter period, and whether the increase of $\mathrm{pH}$ is due to the Trp supplement or to the stressful ante-mortem treatment.

A new strategy, such as the combination of Trp with other compounds or other sources of magnesium (excluding magnesium sulphate) should be considered for further studies, with the aim of reducing stress before slaughter and being able to reduce the negative effect of the use of the halothane gene.

\subsection{References}

Adeola, O., Ball, R.O., 1992. Hypothalamic Neurotransmitter Concentrations and Meat Quality in Stressed Pigs Offered Excess Dietary Tryptophan and Tyrosine. J. Anim. Sci. 70, 1888-1894.

Apple, J.K., Maxwell, C.V., de Rodas, B., Watson, H.B., Johnson, Z.B., 2000. Effect of magnesium mica on performance and carcass quality of growing-finishing swine. J. Anim. Sci. 78, 2135-2143.

Association of Official Analytical Chemists, 1990. Official methods of analysis. $15^{\text {th }}$ ed. Arlington, VA: AOAC.

Barton-Gade, P., Warris, P.D., Brown, S.N., Lambooij, B., 1996. Methods of improving pig welfare and meat quality by reducing stress and discomfort before slaughter - methods of assessing meat quality. In: Proceedings of the EU-Seminar 'New information on welfare and meat quality of pigs as related to handling, transport and lairage conditions, 29-30 June, 23-34. 
Barton-Gade, P., Christensen, L., 1998. Effect of different stocking densities during transport on welfare and meat quality in Danish slaughter pigs. Meat Sci. 48, 237-247.

Caine, W.R., Schaefer, L.A., Aalhus, J.L., Dugan, M.E.R., 2000. Behaviour, growth performance and pork quality of pigs differing in porcine stress syndrome genotype receiving dietary magnesium aspartate hydrochloride. Can. J. Anim. Sci. $80,175-182$.

Cameron, A. C., Trivedi, P. K., 1998. Regression Analysis of Count Data.Cambridge University Press. USA.

Channon, H.A., Payne, A.M., Warner, R.D., 2000. Halothane genotype, pre-slaughter handling and stunning method all influence pork quality. Meat Sci. 56, 291-299.

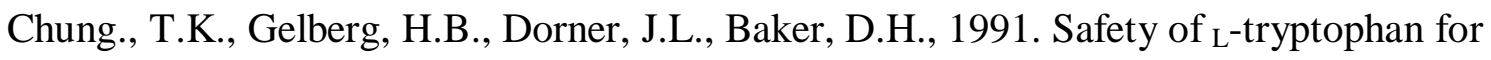
pigs. J. Anim. Sci. 69, 2955-2960.

CIE., 1976. Commission Internationale de l'Éclairage. Colorimetry. Vienna, Austria, Bureau Central de la CIE. Publication $n^{\circ} 15$.

De Smet, S. M., Pauwels, H., De Bie, S., Demeyer, D. I., Callewier, J., Eeckhout, W., 1996. Effect of halothane genotype, breed, feed withdrawal, and lairage on pork quality of Belgian Slaughter Pigs. J. Anim. Sci. 74, 1854-1863.

Dodman, N.H., 1977. Observations on the use of wernberg dip-lift carbon dioxide apparatus for pre-slaughter anaesthesia of pigs. Br. Vet. J. 133, 71-80.

D'Souza, D.N., Warner, R.D., Leury, B.J., Dunshea, F.R., 1998. The Effect of Dietary Magnesium Aspartate Supplementation on Pork Quality. J. Anim. Sci. 76, 104109.

D'Souza, D. N., Warner, R. D., Dunshea, F. R., Leury, B. J., 1999. Comparison of different dietary magnesium supplements on pork quality. Meat Sci. 51, 221225.

EC (European Community), 1993 Directive 93/119/EC on the protection of animals at the time of slaughter or killing. European Community Official Journal 320, 2134.

EFSA, 2004. Welfare aspects of animal stunning and killing method. In: Scientific report of the Scientific Panel for Animal Health and Welfare on a request from the Commission. Question $n^{\text {o }}$ EFSA-Q-2003-093. Accepted 15 ${ }^{\text {th }}$ June 2004. Brussels, Belgium. Available on 14/12/06 at URL: http://www.efsa.eu.int/ 
science/ahaw/ahaw_opinions/495/opinion_ahaw_02_ej45_stunning_report_v2_e n1.pdf.

Etherington, D.J., Wardale, R.J., 1982. The mononuclear cell population in rat leg muscle: its contribution to the lysosomal wnzyme activities of whole muscle extracts. J Cell Sci. 58, 139-148.

Etherington, D.J., Taylor, M.A.J., Wakefield, D.K., Cousins, A., Dransfield, E., 1990. Proteinase (cathepsine B, D, L and calpains) levels and conditioning rates in normal, electrically stimulated and high-ultimate $\mathrm{pH}$ chicken muscle. Meat Sci. 28, 99-109.

Fàbrega, E., Diestre, A., Carrión, D., Font, J., Manteca, X., 2002. Effect of the halothane gene on pre-slaughter mortality in two Spanish commercial pig abattoirs. Anim. Welf. 11, 449-452.

Fàbrega, E., Tibau, J., Soler, J., Fernández, J., Font, J., Carrión, D., Diestre, A., Manteca, X., 2003. Feeding patterns, growth performance and carcass traits in group-housed growing-finishing pigs : the effect of terminal sire line, halothane genotype and age. Anim. Sci. 77, 11-21.

Fernandez, X., Meunier-Salaun, M.C., Ecolan, P., Mormède, P., 1995. Interactive effect of food deprivation and agonistic behavior on blood parameters and muscle glycogen in pigs. Physiol. Behav. 58, 337-345.

Fernstrom, J.D., Wurtman, R.J., 1971. Brain-serotonin content: Physiological dependence on plasma tryptophan levels. Science 173, 149-152.

Forslid, A., 1987. Transcient neocortical, hippocampal and amygdaloid EEG silence induced by one minute inhalation of hig concentration $\mathrm{CO}_{2}$ in swine. Acta Physiol. Scand. 130, 1-10.

Frederick, B., van Heugten, E., See, M.T., 2004. Timing of magnesium supplementation administered through drinking water to improve fresh and stored pork quality. J. Anim. Sci. 82, 1454-1460.

Frederick, B., van Heugten, E., Hanson, D.J., See, M.T., 2006. Effects of supplemental magnesium concentration of drinking water on pork quality. J. Anim. Sci. 84, 185-190.

Fujii, J., Otsu, K., Zorzato, F., Leon, S.D., Khanna, V.K., Weiler, J.E., O’Brien, P.J., Maclennan, D.H., 1991. Identification of a mutation in porcine ryanodine receptor associated with malignant hyperthermia. Science 253, 448-451. 
Geers, R., Bleus, E., Van Schie, T., Ville, H., Gerard, H., Janssens, S., Nackaerts, G., Decuypere, E., Jourquin, J., 1994. Transport of pigs different with respect to halothane gene : stress assessment. J. Anim. Sci. 72, 2552-2558.

Gispert, M., Diestre, A., 1994. Classification of pig carcasses in Spain: a step towards harmonization in the European Community. Tecni-Porc 17, 29-32.

Gispert, M., Guàrdia, M.D., Diestre, A., 1996. La mortalidad durante el transporte y la espera en porcinos destinados al sacrificio. Eurocarne 45, 73-79.

Gispert, M., Valero, A., Oliver, M.A., Diestre, A., 1997. Problemas asociados a la falta de grasa en las canales porcinas. Eurocarne 61(Noviembre 97), 27-32.

Gispert, M., Faucitano, L., Oliver, M.A., Guàrdia, M.D., Coll, C., Siggens, K., Harvey, K., Diestre, A., 2000. A survey of pre-slaughter conditions, halothane gene frequency and carcass and meat quality in five Spanish pig commercial abattoirs. Meat Sci. 55, 97-106.

Gispert, M., Font i Furnols, M., 2007. Evolución y situación de la cabaña porcina española. Eurocarne 161 (Noviembre 2007), 1-10.

Gregory, N.G., Moss, B., Leeson, R., 1987. An assessment of carbon dioxide stunning in pigs. Veterinary Record 121, 517-518.

Guàrdia, M. D., Estany, J., Balasch, S., Oliver, M.A., Gispert, M., Diestre, A., 2004. Risk assessment of PSE condition due to pre-slaughter conditions and RYR1 gene in pigs. Meat Sci. 67, 471-478.

Guzik, A.C., Matthews, J.O., Kerr, B.J., Bidner, T.D., Southern, L.L., 2006. Dietary tryptophan effects on plasma and salivary cortisol and meat quality in pigs. J. Anim. Sci. 84, 2251-2259.

Hamilton, D. N., Ellis, M., Hemann, M. D., McKeith, F. K., Miller, K. D., Purser, K. W., 2002. The impact of Longissimus glycolytic potential and short-term feeding of magnesium sulfate heptahydrate prior to slaughter on carcass characteristics and pork quality. J. Anim. Sci. 80, 1586-1592.

Henry, Y., Sève, B., Colléaux, Y., Ganier, P., Saligaut, C., Jégo, P., 1992. Interactive effects of dietary levels of tryptophan and protein on voluntary feed intake and growth performance in pigs, in relation to plasma free amino acids and hypothalamic serotonin. J. Anim. Sci. 70, 1873-1887. 
Henry, Y., Sève, B., Mounier, A., Ganier, P., 1996. Growth Performance and Brain Neureotransmitters in Pigs as Affected by Tryptophan, Protein and Sex. J. Anim. Sci. 74, 2700-2710.

Hernández, P., Zomeño, L., Ariño, B., Blasco, A., 2004. Antioxidant, lipolytic and proteolytic enzyme activities in pork meat from different genotypes. Meat Sci. $66,525-529$.

Honikel, K.O., 1996. Reference methods supported by OECD and their use in Mediterranean meat products. Food Chem. 54(4), 573-582.

Honkavaara, M., 1988. Influence of PSE pork on the quality and economics of cooked, cured ham and fermented dry sausage manufacture. Meat Sci. 24, 201-207.

Jensen, P., Barton-Gade, P.A., 1985. Performance and carcass characteristics with known genotypes for halothane susceptibility. Ludvigsen, J. B. (Eds.), Stress susceptibility and meat quality in pigs, European Association of Animal. Production Publication. 33: 80-87.

Kietzmann, M., Jablonski, H., 1985. Blocking of stress in swine with magnesium aspartate hydrochloride. Prakt. Tierz. 661, 331.

Lambooij.E., 2007. Transport of pigs. In: Grandin T. (Eds.), Livestock Handling and Transport. CABI Publishing, USA, pp. 228-244.

Le Floc'h, N., Seve, B., 2007. Biological roles of tryptophan and its metabolism: Potential implications for pig feeding. Livest. Sci. 112, 23-32.

Leathwood, P.D., 1987. Tryptophan availability and serotonin synthesis. Proceedings of the Nutrition Society 46(1), 143-156.

Li, Y.Z., Kerr, B.J., Kidd, M.T., Gonyou, H.W., 2006. Use of supplementary tryptophan to modify the behaviour of pigs. J. Anim. Sci. 84, 212-220.

Lowry, O.H., Rosebrough, N.J., Farr, A.L., Randall, R.J., 1951. Protein measurement with the Folin-Phenol reagents. J. Biol. Chem. 193, 265-275.

Moelich, E.I., Hoffman, L.C., Conradie, P.J., 2003. Sensory and functional meat quality characteristics of pork derived from three halothane genotypes. Meat Sci. 63, 333-338.

Møller, A., 1980. Analysis of Warner Bratzler shear force pattern with regard to myofibrilar and connective tissue components of tenderness. Meat Sci. 5, 247260. 
Murray, A.C., Jones, S.D.M., Sather, A.P., 1989. The effect of preslaughter feed restriction and genotype for stress susceptibility on pork lean quality and composition. Can. J. Anim. Sci. 69, 83-91.

Oliver, M.A., Gispert, M., Diestre, A., 1993. The effects of breed and halothane sensitivity on pig meat quality. Meat Sci. 35, 105-118.

Oliver, M.A., Gispert, M., Coll, C., Guàrdia, M.D., Diestre, A., 2001. Incidencia de carne PSE y DFD en canales comerciales de cerdo en cinco mataderos españoles: influencia de factores antes del sacrificio. Eurocarne 100, 101-109.

O'Quinn, P.R., Nelssen, J.L., Unruh, J.A., Goodband, R.D., Woodworth, J. C., Tokach, M.D., 2000. Effects of feeding modified tall oil and supplemental potassium and magnesium on growth performance, carcass characteristics, and meat quality of growing-finishing pigs. Can. J. Anim. Sci. 80, 443-449.

Panella, N., Font i Furnols, M., Tibau, J., Soler, J., Oliver, M.A., Gil, M., 2005. Effect of pig genotype and magnesium - tryptophan supplemented diets on the meat sensorial attributes and textural properties. Proceedings of the $51^{\text {st }}$ International Congress of Meat Science and Technology, 124-128. Baltimore, USA,

Panella-Riera, N., Dalmau, A., Fàbrega, E., Font i Furnols, M., Gispert, M., Tibau, J., Soler, J., Velarde, A., Oliver, M.A., Gil, M., 2008. Effect of supplementation with $\mathrm{MgCO}_{3}$ and $\mathrm{L}_{\mathrm{C}}$-tryptophan on the welfare and on the carcass and meat quality of two halothane pig genotypes (NN and nn). Livest. Sci. 115, 107-117.

Peeters, E., Neyt, A., Beckers, F., Smet, S.M.D., Aubert, A.E., Geers, R., 2005. Influence of supplemental magnesium, tryptophan, vitamin $\mathrm{C}$, and vitamin $\mathrm{E}$ on stress responses of pigs to vibration. J. Anim. Sci. 83, 1568-1580.

Pérez, M.P., Palacio, J., Santolaria, M.P., Aceña, M.C., Chacón, G., Gascón, M., Calvo, J.H., Zaragoza, P., Beltran, J.A., García-Belenguer, S., 2002. Effect of transport time on welfare and meat quality in pigs. Meat Sci. 61, 425-433.

Plastow, G.S., Carrión, D., Gil, M., Garcia-Regueiro, J.A., Font-i-Furnols, M., Gispert, M., Oliver, M.A., Velarde, A., Guàrdia, M.D., Hortós, M., Rius, M.A., Sárraga, C., Díaz, I., Valero, A., Sosnicki, A., Klont, R., Dornan, S., Wilkinson, J.M., Evans, G., Sargent, C., Davey, G., Connolly, D., Houeix, B., Maltin, C.M., Hayes, H.E., Anandavijayan, V., Foury, A., Geverink, N., Cairns, M., Tilley, R.E., Mormède, P., Blott, S.C., 2005. Quality pork genes and meat production. Meat Sci. 70 (3), 409-421. 
Raj, A.B.M., Gregory, N.G., 1995. Welfare implications of the gas stunning of pigs 1. Determination of aversion to the initial inhalation of carbon dioxide or argon. Anim. Welf. 4, 273-280.

Raj, A.B.M., Gregory, N.G., 1996. Welfare implications of the gas stunning of pigs 2. Stress of induction of anaesthesia. Anim. Welf. 5, 71-78.

Raj, A.B.M., 1999. Behaviour of pigs exposed to mixtures of gases and the time required to stun and kill them: welfare implications. Veterinary Record 144, 165-168.

Raj, A.B.M., 2004. $\mathrm{CO}_{2}$ and other gases. In: Jensen, W.K., Devine, C., DIKEMAN, M. (Eds.), Encyclopedia of Meat Sciences. Elsevier, UK, pp. 1348-135.

Rodríguez, P., Dalmau, A., Ruiz-de-la-Torre, J.L., Manteca, X., Jensen, E.W., Rodriguez, B., Litvan, H., Velarde, A., 2008. Assessment of unconsciousness during carbon dioxide stunning in pigs. Animal Welfare, 17: 341-349.

SAS, 2001. SAS for Windows release v.8.2. Cary, North Carolina, USA. SAS Institute Inc.

Schaefer, A.L., Murray, A.C., Tong, A.K.W., Jones, S.D.M., Sather, A.P., 1993. The effect of ante mortem electrolyte therapy on animal physiology and meat quality in pigs segregating and the halothane gene. Can. J. Anim. Sci. 73, 231-240.

Stryer, L., 1988. Biochemistry. W.H.Freeman \& Co. New York.

Velarde, A., Gispert,V., Faucitano, L., Alonso, P., Manteca, X., Diestre,A., 2001. Effects of the stunning procedure and the halothane genotype on meat quality and incidence of haemorrhages in pigs. Meat Sci. 58, 313-319.

Velarde, A., Cruz, J., Gispert, M., Carrión, D., de la Torre, L.R., Diestre, A., Manteca, X., 2007. Aversion to carbon dioxide stunning in pigs: effect of the carbon dioxide concentration and the halothane genotype. Anim. Welf. 16, 513-522.

Warriss, P. D., 1998. The welfare of slaughter pigs during transport. Animal Welfare 7, $365-381$. 


\subsection{Figures}

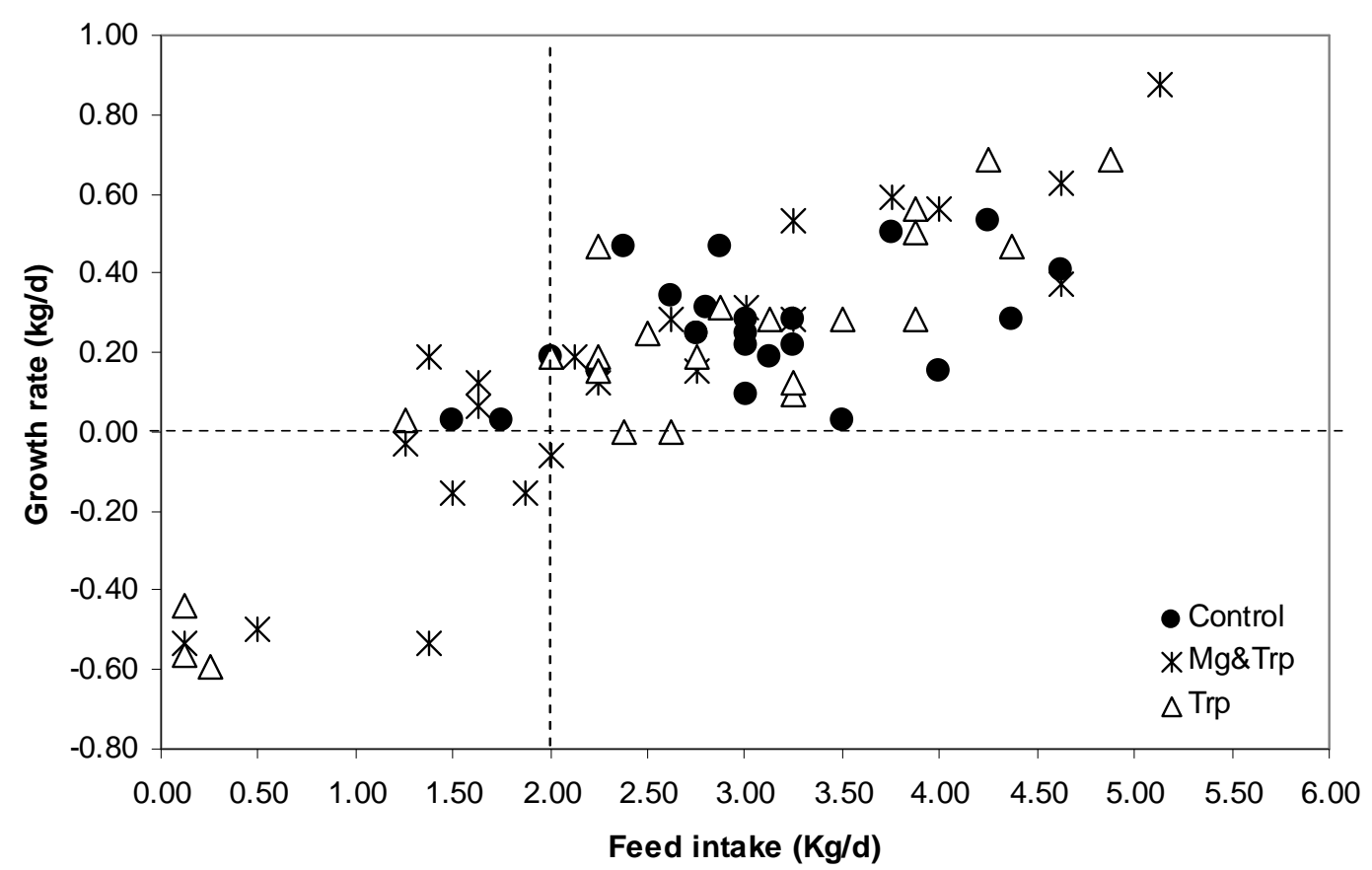

Figure IV.3-1. Relationship between feed intake (kg/day) and growth rate (kg/day) among diets. 


\subsection{Tables}

Taula IV.3-1. Feed composition of experimental and control diets (\%).

Diets

\begin{tabular}{lccc}
\cline { 2 - 4 } & C & Mg\&Trp & Trp \\
\hline Humidity (\%) & 11.80 & 11.47 & 11.80 \\
Ash (\%) & 6.79 & 6.78 & 6.87 \\
Crude fiber (\%) & 3.12 & 3.40 & 3.24 \\
Crude protein (\%) & 16.80 & 18.54 & 18.4 \\
Ether extract (\%) & 6.84 & 6.30 & 6.19 \\
Magnesium (\%) & 0.21 & 0.40 & 0.20 \\
Tryptophan (\%) & 0.21 & 0.70 & 0.77 \\
\hline
\end{tabular}

C: Control Diet; Mg\&Trp: Control diet with $\mathrm{Mg}$ and Trp supplementation; Trp: Control diet with Trp supplementation. 
Taula IV.3-2. Number of pigs with feed intake higher and lower than $2 \mathrm{~kg} / \mathrm{d}$, and feed intake (LSM ${ }^{1}$ ) according to the three diets and two genotypes.

\begin{tabular}{|c|c|c|c|c|c|c|c|}
\hline & \multicolumn{3}{|c|}{ Diet } & & \multicolumn{3}{|c|}{ Genotype } \\
\hline & $\mathrm{C}$ & Mg\&Trp & $\operatorname{Trp}$ & Sig & $\mathrm{NN}$ & $\mathrm{nn}$ & Sig \\
\hline \multicolumn{8}{|l|}{ Number of pigs $^{2}$} \\
\hline In the experiment & 23 & 23 & 23 & & 36 & 33 & \\
\hline With feed intake $\geq 2 \mathrm{~kg} / \mathrm{d}$ & $\begin{array}{c}21 \\
(91.3)\end{array}$ & $\begin{array}{c}13 \\
(56.5)\end{array}$ & $\begin{array}{c}19 \\
(82.6)\end{array}$ & & $\begin{array}{c}30 \\
(83.3)\end{array}$ & $\begin{array}{c}23 \\
(69.7)\end{array}$ & \\
\hline With feed intake $<2 \mathrm{~kg} / \mathrm{d}$ & $\begin{array}{c}2 \\
(8.7)\end{array}$ & $\begin{array}{c}10 \\
(43.5)\end{array}$ & $\begin{array}{c}4 \\
(17.4)\end{array}$ & & $\begin{array}{c}6 \\
(16.7)\end{array}$ & $\begin{array}{c}10 \\
(30.3)\end{array}$ & \\
\hline Sig. ${ }^{3}$ & $\mathrm{a}$ & $b$ & $a b$ & $* *$ & - & - & ns \\
\hline
\end{tabular}

Feed intake $^{1}$

$$
\text { Total feed intake }(\mathrm{kg} / \mathrm{d})
$$

$\begin{array}{cc}3.00 & 2.40 \\ (0.19) & (0.19)\end{array}$

2.67

(0.19) ns

3.26

(0.16)

2.13

$3.09 \quad 3.20$

3.13 ns

3.07

2.58

Pigs with feed intake $\geq 2 \mathrm{~kg} / \mathrm{d}$

(0.13)

$(0.17)$

(0.14)

(0.11)

(0.13)

Pigs with feed intake $<2 \mathrm{~kg} / \mathrm{d}$

$1.69^{\mathrm{a}}$
$(0.41)$

$1.26^{\mathrm{a}}$

$0.44^{\mathrm{b}}$

1.21

1.06

(0.26)

(0.19)

ns

C: Control Diet; Mg\&Trp: Control diet with $\mathrm{Mg}$ and Trp supplementation; Trp: Control diet with $\operatorname{Trp}$ supplementation; ns: $\mathrm{P}>0.1 ;{ }^{*}: \mathrm{P}<0.05 ;{ }^{* *}: \mathrm{P}<0.01$ and $* * *: \mathrm{P}<0.001$.

${ }^{1}$ LSM: Least square means and standard error within brackets.

${ }^{2}$ Number of pigs and percentage within brackets.

${ }^{3}$ Columns with different letter were significantly different at a level of $\mathrm{P}<0.05$. The probability of showing feed intake $<2 \mathrm{~kg} /$ day was tested with a GENMOD procedure. 
Taula IV.3-3. Mortality of pigs during the pre-slaughter period according to the three diets and two genotypes.

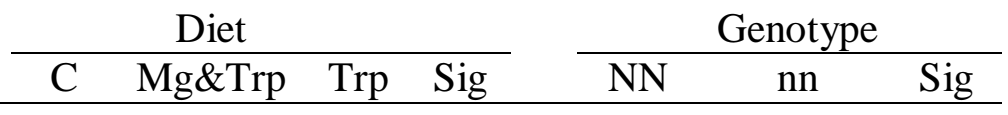

Mortality considering all pigs included in the experiment

$\begin{array}{lccccccc}\mathrm{n} & 23 & 23 & 23 & 36 & 33 & \\ \text { deaths } & 3 & 2 & 0 & \mathrm{~ns} & 0 & 5 & * \\ (\%) & 13.0 & 8.7 & 0.0 & & 0.0 & 15.2 & \end{array}$

Mortality between pigs with feed intake $>2 \mathrm{~kg} / \mathrm{d}$

\begin{tabular}{lccccccc}
$\mathrm{n}$ & 21 & 13 & 19 & & 30 & 23 & \\
deaths & 1 & 1 & 0 & $\mathrm{~ns}$ & 0 & 2 & $\mathrm{~ns}$ \\
$(\%)$ & 4.8 & 7.7 & 0.0 & & 0.0 & 8.7 & \\
\hline
\end{tabular}

C: Control Diet; Mg\&Trp: Control diet with Mg and Trp supplementation; Trp: Control diet with Trp supplementation; ns: $\mathrm{P}>0.1$ and $*$ : $\mathrm{P}<0.05$. 
Taula IV.3-4. Time taken to cross the raceway ${ }^{1}$, Percentage of pigs showing retreat attempts and time to perform the first retreat attempt according to the three diets and two genotypes. Pigs with feed intakes $>2 \mathrm{~kg}$ /day are considered.

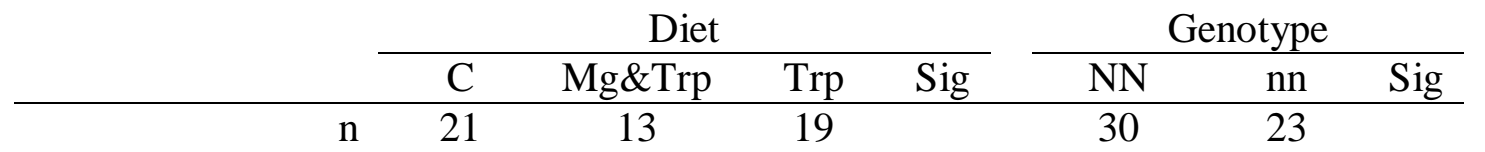

Time to cross (s)

$\begin{array}{lccccccc}\text { the raceway } & 18.4 & 30.7 & 32.3 & \mathrm{~ns} & 26.1 & 26.7 & \mathrm{~ns} \\ & (4.8) & (12.0) & (7.4) & & (5.9) & (6.5) & \\ \text { the ramp } & 41.2 & 50.6 & 51.3 & \mathrm{~ns} & 49.7 & 42.7 & \mathrm{~ns} \\ & (7.8) & (10.1) & (10.9) & & (7.6) & (7.6) & \\ \text { the entrance } & 38.6 & 26.8 & 42.2 & \mathrm{~ns} & 43.2 & 27.3 & * \\ & (8.2) & (9.6) & (7.2) & & (6.8) & (5.2) & \\ \text { all the way } & 98.2 & 108.1 & 125.8 & \mathrm{~ns} & 119.0 & 96.7 & \mathrm{~ns} \\ & (10.7) & (25.2) & (17.0) & & (13.5) & (11.5) & \end{array}$

Pigs showing retreat attempts $(\%)$

$\begin{array}{lccccccc}\text { in the raceway } & 4.8 & 15.4 & 21.1 & \mathrm{~ns} & 10.0 & 17.4 & \mathrm{~ns} \\ \text { in the ramp } & 47.6 & 38.5 & 36.8 & \mathrm{~ns} & 50.0 & 30.4 & \mathrm{~ns} \\ \text { in the entrance } & 14.3 & 7.7 & 10.5 & \mathrm{~ns} & 20.6 & 0.0 & * \\ \text { all the way } & 57.1 & 46.2 & 63.2 & \mathrm{~ns} & 66.7 & 43.5 & \mathrm{~ns}\end{array}$

C: Control Diet; Mg\&Trp: Control diet with $\mathrm{Mg}$ and Trp supplementation; Trp: Control diet with $\operatorname{Trp}$ supplementation; ns: $\mathrm{P}>0.1$ and $*: \mathrm{P}<0.05$.

${ }^{1}$ Means and standard error 
Taula IV.3-5. Carcass and meat quality traits of diet and genotype effects,

measured considering pigs with feed intake higher than $2 \mathbf{k g} / \mathrm{day}$.

\begin{tabular}{|c|c|c|c|c|c|c|c|}
\hline & \multicolumn{3}{|c|}{ Diet $^{1}$} & & \multicolumn{3}{|c|}{ Genotype $^{1}$} \\
\hline & $\mathrm{C}$ & Mg\&Trp & Trp & Sig. & $\mathrm{NN}$ & $\mathrm{nn}$ & Sig. \\
\hline $\mathrm{n}$ & 21 & 13 & 19 & & 30 & 23 & \\
\hline \multicolumn{8}{|l|}{ Carcass traits } \\
\hline Body weight (kg) & $\begin{array}{c}109.5 \\
(1.8)\end{array}$ & $\begin{array}{l}109.8 \\
(2.3)\end{array}$ & $\begin{array}{c}110.4 \\
(1.8)\end{array}$ & ns & $\begin{array}{l}113.6 \\
(1.4)\end{array}$ & $\begin{array}{l}106.2 \\
(1.8)\end{array}$ & $* *$ \\
\hline Carcass weight (kg) & $\begin{array}{l}85.1 \\
(1.4)\end{array}$ & $\begin{array}{l}84.2 \\
(1.8)\end{array}$ & $\begin{array}{l}85.4 \\
(1.4)\end{array}$ & ns & $\begin{array}{l}85.5 \\
(1.4)\end{array}$ & $\begin{array}{l}84.2 \\
(1.4)\end{array}$ & ns \\
\hline Lean content $(\%)$ & $\begin{array}{c}57.5 \\
(0.63)\end{array}$ & $\begin{array}{c}56.6 \\
(0.79)\end{array}$ & $\begin{array}{c}56.6 \\
(0.62)\end{array}$ & ns & $\begin{array}{c}52.7 \\
(0.50)\end{array}$ & $\begin{array}{c}61.1 \\
(0.62)\end{array}$ & $* * *$ \\
\hline Carcass length $(\mathrm{cm})$ & $\begin{array}{l}81.6 \\
(0.9)\end{array}$ & $\begin{array}{l}81.3 \\
(1.1)\end{array}$ & $\begin{array}{l}82.0 \\
(0.9)\end{array}$ & ns & $\begin{array}{l}85.8 \\
(0.7)\end{array}$ & $\begin{array}{l}77.5 \\
(0.9)\end{array}$ & $* * *$ \\
\hline $\begin{array}{r}\text { Fat depth at last rib level (FOM; } \\
\mathrm{mm})\end{array}$ & $\begin{array}{l}12.9 \\
(0.6)\end{array}$ & $\begin{array}{l}13.4 \\
(0.8)\end{array}$ & $\begin{array}{l}13.5 \\
(0.6)\end{array}$ & ns & $\begin{array}{l}16.6 \\
(0.5)\end{array}$ & $\begin{array}{l}10.0 \\
(0.6)\end{array}$ & $* * *$ \\
\hline Conformation & $\begin{array}{c}2.0 \\
(0.1)\end{array}$ & $\begin{array}{c}2.1 \\
(0.1)\end{array}$ & $\begin{array}{c}2.0 \\
(0.1)\end{array}$ & & $\begin{array}{l}2.9 \\
(0.1)\end{array}$ & $\begin{array}{l}1.2 \\
(0.1)\end{array}$ & \\
\hline
\end{tabular}

\section{Meat quality parameters}

$\mathrm{pH}$ at $45 \mathrm{~min}$

$\begin{array}{cccccccl}\text { LT } & 5.96^{\mathrm{b}} & 5.96^{\mathrm{b}} & 6.15^{\mathrm{a}} & * & 6.47 & 5.58 & * * * \\ & (0.06) & (0.07) & (0.06) & & (0.05) & (0.06) & \\ \mathrm{SM} & 6.09 & 6.11 & 6.21 & & 6.47 & 5.79 & * * * \\ & (0.06) & (0.07) & (0.05) & & (0.04) & (0.05) & \end{array}$

$\mathrm{pH}$ at $24 \mathrm{~h}$

$\begin{array}{cccccccc}\text { LT } & 5.47 & 5.52 & 5.59 & & 5.60 & 5.46 & * \\ & (0.05) & (0.06) & (0.05) & \text { ns } & (0.04) & (0.05) & \\ \text { SM } & 5.59 & 5.71 & 5.71 & & 5.75 & 5.58 & * \\ & (0.06) & (0.07) & (0.06) & \text { ns } & (0.05) & (0.06) & *\end{array}$

Electrical Conductivity $24 \mathrm{~h}(\mathrm{mS})$

$\begin{array}{rccccccc}\text { LT } & 7.0 & 7.1 & 6.0 & \dagger & 4.2 & 9.3 & * * * \\ & (0.4) & (0.5) & (0.4) & & (0.3) & (0.4) & \\ \text { SM } & 8.4 & 7.3 & 7.0 & & 5.2 & 9.9 & * * * \\ & (0.5) & (0.6) & (0.5) & \text { ns } & (0.4) & (0.5) & \\ \text { Loin drip loss }(\%) & 8.7 & 8.0 & 7.4 & & 5.1 & 11.0 & * * * \\ & (0.5) & (0.6) & (0.5) & & (0.4) & (0.5) & \\ \text { Colour- L* } & 54.2 & 51.9 & 51.1 & & 50.0 & 54.8 & * * * \\ & (1.1) & (1.4) & (1.1) & \text { ns } & (0.9) & (1.1) & \end{array}$

Incidence of PSE (pH45 $\leq 5.8 ; \%)$

$\begin{array}{rrrrrrrr}\text { LT } & 31.6 & 33.3 & 26.3 & \mathrm{~ns} & 0.0 & 75.0 & * * * \\ \mathrm{SM} & 21.1 & 25.0 & 26.3 & \mathrm{~ns} & 0.0 & 60.0 & * * * \\ & & & & & & & \end{array}$

Incidence of DFD $(\mathrm{pHu} \geq 6.0 ; \%)$

$\begin{array}{cccccccc}\text { LT } & 0.0 & 8.3 & 10.5 & \text { ns } & 6.7 & 5.0 & \text { ns } \\ \text { SM } & 0.0^{\mathrm{b}} & 8.3^{\mathrm{b}} & 21.1^{\mathrm{a}} & * & 13.3 & 5.0 & \text { ns }\end{array}$

${ }^{1}$ Least square means and standard error within brackets.

C: Control Diet; Mg\&Trp: Control diet with Mg and Trp supplementation; Trp: Control diet with Trp supplementation; SM: Semimembranosus muscle; LT: Longissimus thoracis muscle; PSE: Pale, Soft and Exudative; DFD: Dark, Firm and Dry; ns: $\mathrm{P}>0.1 ; \uparrow: \mathrm{P}<0.1 ; *: \mathrm{P}<0.05 ; * *: \mathrm{P}<0.01$ and $* * *: \mathrm{P}<0.001$. 
Taula IV.3-6. Percentage of carcasses with skin lesions according to the three diets and two genotypes. Pigs with feed intake $>2 \mathrm{~kg} / \mathrm{day}$ are considered.

\begin{tabular}{|c|c|c|c|c|c|c|c|}
\hline & \multicolumn{4}{|c|}{ Diet $^{1}$} & \multicolumn{3}{|c|}{ Genotype $^{1}$} \\
\hline & $\mathrm{C}$ & Mg\&Trp & Trp & Sig & $\mathrm{NN}$ & $\mathrm{nn}$ & Sig \\
\hline $\mathrm{n}$ & 21 & 13 & 19 & & 30 & 23 & \\
\hline Skin lesions (\%) & 85.7 & 100 & 94.7 & ns & 93.3 & 91.3 & ns \\
\hline Severity of skin lesions & & & & & & & \\
\hline No skin damage (1) & 16.7 & 0.0 & 5.6 & & 6.9 & 10.5 & \\
\hline Slight skin damage (2) & 55.6 & 16.7 & 33.3 & & 37.9 & 36.8 & \\
\hline Skin damage affecting quality (3) & 22.2 & 50.0 & 50.0 & & 37.9 & 42.1 & \\
\hline Severe skin damage (4) & 5.6 & 33.3 & 11.1 & & 17.2 & 10.5 & \\
\hline Sig. ${ }^{1}$ & $\mathrm{~b}$ & $\mathrm{a}$ & $\mathrm{b}$ & $* *$ & - & - & ns \\
\hline
\end{tabular}

C: Control Diet; Mg\&Trp: Control diet with Mg and Trp supplementation; Trp: Control diet with Trp supplementation; ns: $\mathrm{P}>0.05$; **: $\mathrm{P}<0.01$.

${ }^{1}$ Columns with different letter were significantly different at a level of $\mathrm{P}<0.05$. The probability of showing more intense skin lesions (from 1 to 4 ) was tested with a GENMOD procedure. Diet effect: $\mathrm{P}=0.0025$; Genotype effect: $\mathrm{P}=0.5769$. 
Taula IV.3-7. Significance levels of meat quality variables of diet and genotype effects, measured considering all pigs and those pigs with feed intake higher than $2 \mathrm{~kg} /$ day.

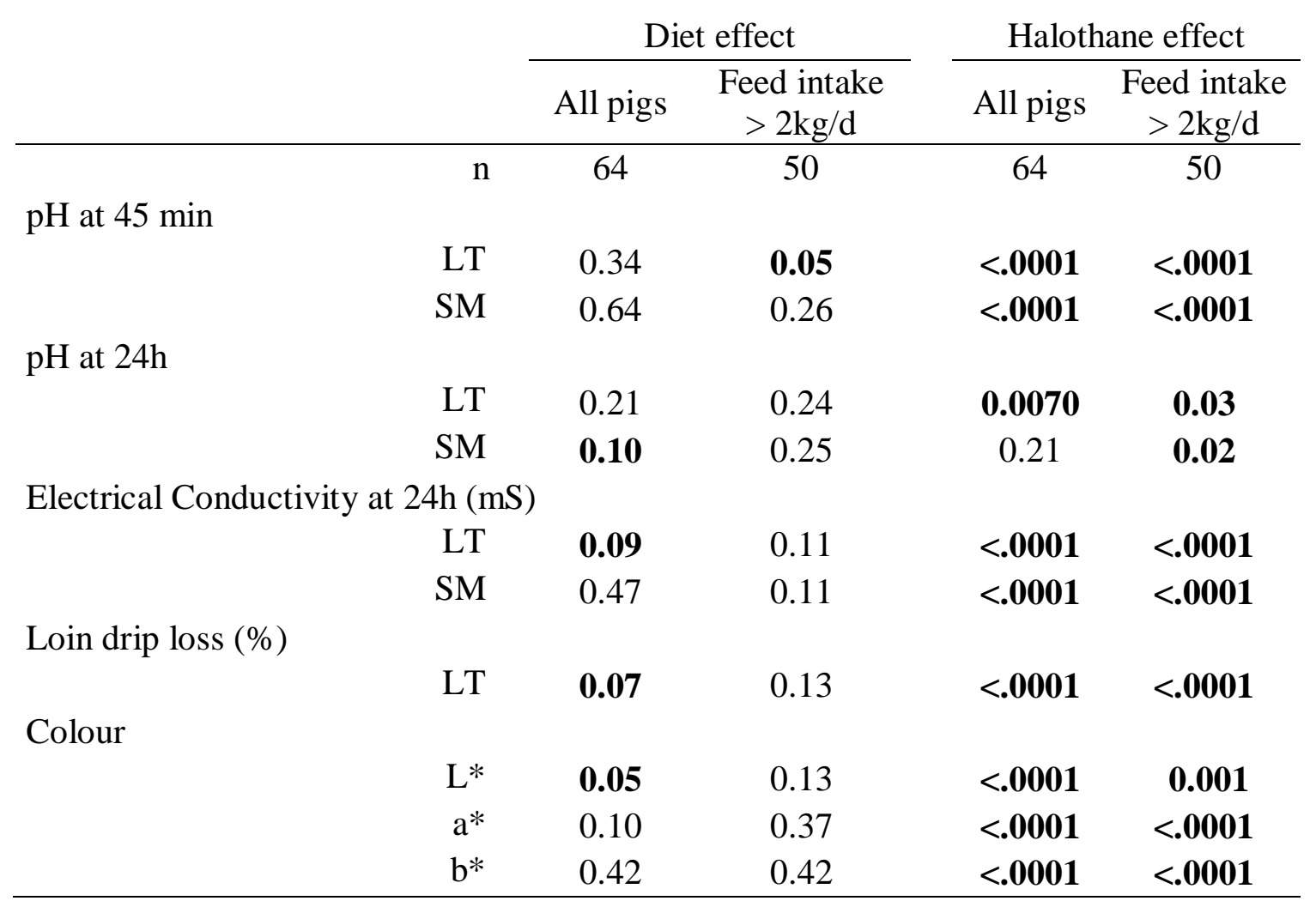

SM: Semimembranosus muscle; LT: Longissimus thoracis muscle.

$\mathrm{P}$ values lower than 0.1 are showed in bold. 
Table IV.3-8. Enzymatic activity variables ${ }^{1}$ (cathepsin $B$ and cathepsin $B+L$ ) and instrumental texture variables ${ }^{1}$ after Warner-Bratzler Shear force test, among diets and halothane genotype. Pigs with feed intake $>\mathbf{2} \mathrm{kg} /$ day are considered.

\begin{tabular}{cccccccccc} 
& \multicolumn{4}{c}{ Diet } & & \multicolumn{3}{c}{ Genotype } \\
\cline { 3 - 5 } \cline { 7 - 9 } & & $\mathrm{C}$ & Mg\&Trp & Trp & Sig & & NN & nn & Sig \\
\hline $\mathrm{n}$ & 21 & 13 & 19 & & & 30 & 23
\end{tabular}

Enzymatic activity $^{2}$

$\begin{array}{rrrrrrrr}\text { CAT B (nIU) } & & & & & & & \\ \text { LT } & 32.3 & 26.3 & 22.1 & \text { ns } & 24.2 & 30.5 & \text { ns } \\ & (3.1) & (3.9) & (3.0) & & (2.4) & (3.0) & \\ \text { SM } & 79.8 & 72.9 & 71.1 & \text { ns } & 71.4 & 77.8 & \text { ns } \\ & (6.6) & (8.3) & (6.5) & & (5.2) & (6.5) & \\ \text { CAT B+L (nIU) } & & & & & & & \\ \text { LT } & 161.9 & 159.0 & 151.4 & \text { ns } & 135.2 & 179.6 & * * \\ & (13.5) & (17.0) & (17.0) & & (10.7) & (13.3) & \\ \text { SM } & 251.6 & 255.7 & 281.1 & \text { ns } & 243.4 & 282.2 & * \\ & (16.1) & (20.2) & (15.9) & & (12.7) & (15.8) & \end{array}$

Instrumental texture

\begin{tabular}{rccccccc}
\hline Shear Force $(\mathrm{N})$ & 51.2 & 50.4 & 48.2 & $\mathrm{~ns}$ & 50.5 & 49.4 & $\mathrm{~ns}$ \\
& $(2.2)$ & $(2.7)$ & $(2.3)$ & & $(1.8)$ & $(2.2)$ & \\
Initial Yield Force $(\mathrm{Ncm})$ & 72.8 & 72.0 & 70.4 & $\mathrm{~ns}$ & 69.3 & 74.1 & $\mathrm{~ns}$ \\
& $(3.3)$ & $(4.1)$ & $(3.5)$ & & $(2.7)$ & $(3.3)$ & \\
Total Work $\left(\mathrm{kg} . \mathrm{s} / \mathrm{cm}^{2}\right)$ & 6.7 & 6.1 & 6.1 & $\mathrm{~ns}$ & 6.4 & 6.2 & $\mathrm{~ns}$ \\
& $(0.3)$ & $(0.3)$ & $(0.3)$ & & $(0.2)$ & $(0.3)$ & \\
\hline
\end{tabular}

C: Control Diet; Mg\&Trp: Control diet with $\mathrm{Mg}$ and Trp supplementation; Trp: Control diet with Trp supplementation; LT: Longissimus thoracis muscle; SM: Semimembranosus muscle; CAT B: cathepsin B activity; CAT B+L: cathepsin B+L activity; ns: $\mathrm{P}>0.1$ *: $\mathrm{P}<0.05$ and **: $\mathrm{P}<0.01$.

${ }^{1}$ Least square means and standard error within brackets.

${ }^{2}$ Results are given in nIU (nmol.min ${ }^{-1}$.g proteine $\mathrm{e}^{-1}$ ) 
